\title{
Evaluation of Coriander (Coriandrum sativum L.) Varieties in Prayagraj Agro-climatic Conditions
}

\author{
Lavanya Gandepalli* and V. M. Prasad \\ Department of Horticulture, Naini Agricultural Institute, SHUATS, Prayagraj, \\ Uttar Pradesh, India \\ *Corresponding author
}

\section{A B S T R A C T}

\section{Keywords \\ Coriander varieties, Growth, Yield, quality, Randomized block design}

Article Info

Accepted:

10 November 2020

Available Online:

10 December 2020
Coriander (Coriandrum sativum L.) is an important seed spice cultivated in India. The leaves of coriander \& its seeds are widely used as a condiment asual as a spice. The present experiment was carried out in Vegetable Research Farm, Department Of Horticulture, Sam Higginbottom University Of Agriculture, Technology and Sciences. Prayagraj during October (2019)- March (2020). The present experiment is on "Evaluation of coriander varieties in prayagraj Agro-climatic conditions". The experiment was laid out in randomized block design with three replications. Study consists of eight varieties i.e. WS-201, SURUCHI, JYOTI, DESI, GREEN AROMA, VIKRAM, SWATHI, RAMSES. During this study we observed significant differences among the varieties based on its growth, yield, quality parameters. The results revealed that the maximum height was observed in Green Aroma ( $65.57 \mathrm{~cm}$ ), number of branches per plant (22.77), days to $50 \%$ flowering(126.9) number of umbellets per umbel ( 7.40) number of flowers per umbellate (8.63) maximum yield and quality was observed in DESI. Leaf yield $(419.52 \mathrm{~kg}$ ), seed yield per plot ( $214.04 \mathrm{~kg}$ ), T.S.S ( $6.20^{\circ}$ brix), protein $(27.04 \%)$, ascorbic acid( 208.60 $\mathrm{mg} / 100 \mathrm{~g}$ ). It concludes that GREEN AROMA and DESI varieties of coriander were found superior in terms of growth, yield and quality.

\section{Introduction}

Coriander (Coriandrum sativum $L$ ) is an annual spice herb belongs to the family apiaceae with chromosome number $2 n=22$. The plant is indigenous to southern Europe and Mediterranean region. It is one of the oldest consumed spices in India. India is known as "Home of spices" from ancient times. India is major producer, consumer and exporter of coriander seeds. According to (Peter et al., 2000) annual production is estimated to be 308000 tonnes. In India coriander occupied an area of 46800 ha with production of 56700 tonnes during 2018-2019 (NHB). In Uttar Pradesh spices are grown in an area of about 88204 ha, production 274681 metric ton, productivity 3.114 tonnes per ha. In India it is mainly grown in Rajasthan, Madhya Pradesh, Assam, Gujarat, Orissa, Andhra Pradesh, Tamilnadu and Karnataka. Seeds of coriander contain essential oils\& the oil can be used in pharmaceutical industries, leaves of coriander is good source of Vitamin 
C \& it can be used for making chutney, soup etc.

\section{Materials and Methods}

The experiment was carried out at the vegetable research farm, Department of Horticulture, Naini Agricultural Institute, Sam Higginbottom university Of Agriculture, Technology and Sciences, Prayagraj. Prayagraj is situated at an elevation of 78 meters above sea level at $25.87^{0}$

\section{North altitude and $85.15^{\circ}$ of E longitude}

The present experiment was laid out in randomized block design with three replications, and the study consists of eight varieties. fertilizers were applied @ $15 \mathrm{~kg}$ of farm yard manure and 60: 40: $20 \mathrm{~kg} / \mathrm{ha}$ of NPK. Full dose of phosphorous and potassium \& half dose of nitrogen was applied during land preparation and remaining dose of nitrogen was top dressed at 30 days after sowing.

Seeds were soaked in water for 24 hours to enhance the germination. Seeds were germinated in 7-10 days. random plants were selected from each treatment and in each replication were tagged for recording observations on growth, and yield characters i.e plant height, number of branches per plant, number of leaves, days to $50 \%$ flowering, number of umbellets per umbel, number of seeds per umbelleat, leaf yield, seed yield, T.S.S $\left({ }^{\circ} \mathrm{Brix}\right), \quad$ protein, ascorbic acid $(\mathrm{mg} / 100 \mathrm{~g})$.

\section{Results and Discussion}

The entire evaluation varied significantly in terms of plant growth, quality and yield. Regarding plant height maximum plant height $(65.57 \mathrm{~cm})$ was observed in Green aroma and minimum plant height was observed in $(56.26$ $\mathrm{cm}$ ) Swathi. The maximum Number of branches per plant was found by the variety Green Aroma (22.77) and minimum number of branches was Observed in Swathi (15.40).

The variation in plant growth of different coriander varieties were also observed by Carrubba et al., (2002) in coriander, Kalidasu et al., (2008) in Sadhana variety of coriander, Verma et al., (2014) in coriander.

The maximum number of leaves per plant was found by the variety Green Aroma (62.41) and minimum was observed in WS-201 (47.51). For days to $50 \%$ flowering all the varieties showed significant differences in relation to time taken from sowing to flowering significantly minimum period ( 84 days) was taken by Jyothi and maximum time (126.90 days) taken by green aroma.

The maximum number of umbellets per umbel was found highest in Green aroma (7.40) and minimum was observed in Ramses (6.06). Maximum number of flowers per umbellet was recorded in vikram (8.63) and minimum was observed in WS-201 (6.60). The number of seeds per umbellet was recorded in significantly highest in vikram (14.06) and minimum was observed in Suruchi (5.63). The maximum number of umbels was obviously noted in case of green aroma but for other traits like number of umbellet / number of flowers/ umbellet and number of seeds / umbellet Vikram was found to be significantly superior over the other treatments.

These varietal differences may be attributed to inherent nature of the varieties to express themselves in response to climatic and nutritional factors. Similar findings were also reported by Sharma and Bhati (1998) in UD21, UD-41 and CS-6 and Shrihar et al., (1990) in CS-1 and DFWD-7 (Table 1-3). 
Table.1 Performance of coriander varieties based on growth attributes

\begin{tabular}{|c|c|c|c|c|c|c|c|c|c|c|c|}
\hline \multirow[t]{2}{*}{$\begin{array}{l}\text { Treatment } \\
\text { symbols }\end{array}$} & \multirow[t]{2}{*}{$\begin{array}{l}\text { Notation } \\
\text { symbols }\end{array}$} & \multirow[t]{2}{*}{ Varieties } & \multicolumn{3}{|c|}{ Plant height } & \multicolumn{3}{|c|}{$\begin{array}{l}\text { Number } \\
\text { branches/plant }\end{array}$} & \multicolumn{3}{|c|}{$\begin{array}{l}\text { Number } \\
\text { leaves/plant }\end{array}$} \\
\hline & & & $\begin{array}{l}30 \\
\text { days }\end{array}$ & $\begin{array}{l}60 \\
\text { days }\end{array}$ & $\begin{array}{l}90 \\
\text { days }\end{array}$ & $\begin{array}{l}30 \\
\text { days }\end{array}$ & $\begin{array}{l}60 \\
\text { Days }\end{array}$ & $\begin{array}{l}90 \\
\text { days }\end{array}$ & $\begin{array}{l}30 \\
\text { days }\end{array}$ & $\begin{array}{l}60 \\
\text { days }\end{array}$ & $\begin{array}{l}90 \\
\text { days }\end{array}$ \\
\hline$T_{1}$ & $\mathrm{~V}_{1}$ & WS-201 & 14.44 & 36.37 & 61.05 & 3.69 & 10.38 & 19.61 & 19.42 & 30.23 & 47.51 \\
\hline $\mathbf{T}_{2}$ & $\mathrm{~V}_{2}$ & Suruchi & 15.22 & 29.44 & 60.72 & 3.02 & 9.17 & 20.08 & 22.23 & 34.95 & 58.49 \\
\hline $\mathbf{T}_{3}$ & $\mathrm{~V}_{3}$ & Desi & 9.95 & 30.74 & 63.15 & 4.56 & 11.17 & 22.71 & 22.51 & 32.47 & 55.37 \\
\hline$T_{4}$ & $\mathrm{~V}_{4}$ & Jyoti & 18.40 & 33.28 & 60.89 & 5.21 & 13.31 & 16.82 & 19.51 & 29.33 & 48.15 \\
\hline $\mathbf{T}_{5}$ & $\mathrm{~V}_{5}$ & Ramses & 17.18 & 33.59 & 58.88 & 4.11 & 13.17 & 16.18 & 20.78 & 33.07 & 48.25 \\
\hline$T_{6}$ & $\mathrm{~V}_{6}$ & $\begin{array}{l}\text { Green } \\
\text { Aroma }\end{array}$ & 21.38 & 36.82 & 65.57 & 5.92 & 14.24 & 22.77 & 22.75 & 37.69 & 62.41 \\
\hline $\mathbf{T}_{7}$ & $\mathrm{~V}_{7}$ & Vikram & 12.56 & 34.51 & 59.35 & 3.49 & 13.85 & 16.76 & 22.74 & 35.62 & 57.10 \\
\hline$T_{8}$ & $\mathrm{~V}_{8}$ & Swathi & 13.24 & 34.70 & 56.26 & 3.33 & 12.34 & 15.40 & 20.90 & 36.93 & 51.52 \\
\hline \multicolumn{3}{|c|}{ Mean } & 15.30 & 33.68 & 60.73 & 4.17 & 12.21 & 18.79 & 22.75 & 37.69 & 62.41 \\
\hline \multicolumn{3}{|c|}{ F-test } & S & S & S & S & S & S & 19.42 & 29.33 & 47.51 \\
\hline \multirow{2}{*}{\multicolumn{3}{|c|}{ C.D. at $0.5 \%$}} & 2.32 & 2.64 & 2.95 & 0.56 & 2.38 & 3.19 & 2.104 & 4.143 & 6.393 \\
\hline & & & 1.083 & 1.23 & 1.37 & 0.26 & 1.11 & 1.49 & 0.981 & 1.932 & 2.98 \\
\hline
\end{tabular}

Table.2 Performance of coriander varieties based on yield attributes

\begin{tabular}{|c|c|c|c|c|c|c|c|c|}
\hline \multirow{2}{*}{$\begin{array}{l}\text { Treatment } \\
\text { symbols }\end{array}$} & \multirow{2}{*}{$\begin{array}{l}\text { Notation } \\
\text { symbols }\end{array}$} & \multirow[t]{2}{*}{ Varieties } & \multicolumn{3}{|c|}{ Leaf yield } & \multicolumn{3}{|c|}{ Seed yield } \\
\hline & & & $\begin{array}{c}\text { Leaf } \\
\text { yield/plant(gm) }\end{array}$ & $\begin{array}{c}\text { Leaf } \\
\text { yield/plot } \\
(\mathrm{kg})\end{array}$ & $\begin{array}{l}\text { Leaf } \\
\text { Yield } \\
\text { q/ha }{ }^{-1}\end{array}$ & $\begin{array}{c}\text { Seed } \\
\text { yield/plant(gm) }\end{array}$ & $\begin{array}{c}\text { Seed } \\
\text { yield/plot } \\
(\mathrm{kg})\end{array}$ & $\begin{array}{l}\text { seed } \\
\text { Yield } \\
\mathrm{q} / \mathrm{ha}^{-1}\end{array}$ \\
\hline $\mathbf{T}_{1}$ & $\mathrm{~V}_{1}$ & WS-201 & 13.20 & 316.72 & 29.33 & 6.16 & 147.84 & 13.69 \\
\hline $\mathbf{T}_{2}$ & $\mathrm{~V}_{2}$ & Suruchi & 15.40 & 369.52 & 34.21 & 6.37 & 152.80 & 14.15 \\
\hline $\mathbf{T}_{3}$ & $\mathrm{~V}_{3}$ & Desi & 17.48 & 419.52 & 38.84 & 8.92 & 214.04 & 19.82 \\
\hline$T_{4}$ & $\mathrm{~V}_{4}$ & Jyoti & 14.53 & 348.72 & 32.29 & 7.32 & 182.16 & 16.87 \\
\hline$T_{5}$ & $\mathrm{~V}_{5}$ & Ramses & 13.95 & 334.80 & 31.00 & 6.30 & 151.20 & 14.00 \\
\hline$T_{6}$ & $\mathrm{~V}_{6}$ & $\begin{array}{l}\text { Green } \\
\text { Aroma }\end{array}$ & 17.38 & 417.20 & 38.63 & 7.59 & 175.60 & 16.26 \\
\hline $\mathbf{T}_{7}$ & $\mathrm{~V}_{7}$ & Vikram & 13.52 & 324.48 & 30.04 & 4.95 & 118.88 & 11.01 \\
\hline $\mathbf{T}_{8}$ & $\mathrm{~V}_{8}$ & Swathi & 14.81 & 355.36 & 32.90 & 6.05 & 145.20 & 13.44 \\
\hline \multicolumn{3}{|c|}{ Mean } & 15.03 & 360.79 & 33.41 & 6.71 & 160.97 & 14.90 \\
\hline \multicolumn{3}{|c|}{ F-test } & $\mathrm{S}$ & $\mathrm{S}$ & $\mathrm{S}$ & $\mathrm{S}$ & $\mathrm{S}$ & $\mathrm{S}$ \\
\hline \multicolumn{3}{|c|}{ C.D. at 0.5\% } & 1.936 & 46.46 & 4.302 & 0.739 & 17.725 & 1.641 \\
\hline \multicolumn{3}{|c|}{ S.Ed( $(+)$} & 0.903 & 21.662 & 2.006 & 0.344 & 8.264 & 0.765 \\
\hline
\end{tabular}


Table.3 Performance based on flowering and fruiting attributes

\begin{tabular}{|c|c|c|c|c|c|c|}
\hline $\begin{array}{l}\text { Treatment } \\
\text { symbol }\end{array}$ & $\begin{array}{l}\text { Notation } \\
\text { symbol }\end{array}$ & Varieties & $\begin{array}{c}\text { Days to } \\
\mathbf{5 0 \%} \\
\text { flowering }\end{array}$ & $\begin{array}{c}\text { Number of } \\
\text { umbellets/ } \\
\text { umbel }\end{array}$ & $\begin{array}{c}\text { Number of } \\
\text { flowers/umbellet }\end{array}$ & $\begin{array}{c}\text { Number of } \\
\text { seeds/umbellet }\end{array}$ \\
\hline $\mathbf{T}_{1}$ & $\mathrm{~V}_{1}$ & WS-201 & 95.00 & 6.10 & 6.60 & 11.40 \\
\hline $\mathbf{T}_{2}$ & $\mathrm{~V}_{2}$ & Suruchi & 95.33 & 6.60 & 7.26 & 5.63 \\
\hline $\mathbf{T}_{3}$ & $\mathrm{~V}_{3}$ & Desi & 89.66 & 6.53 & 7.60 & 12.06 \\
\hline $\mathbf{T}_{4}$ & $\mathrm{~V}_{4}$ & Jyoti & 84.66 & 6.23 & 7.60 & 10.26 \\
\hline $\mathbf{T}_{5}$ & $\mathrm{~V}_{5}$ & Ramses & 93.33 & 6.06 & 7.46 & 11.26 \\
\hline$T_{6}$ & $\mathrm{~V}_{6}$ & $\begin{array}{l}\text { Green } \\
\text { Aroma }\end{array}$ & 126.09 & 7.40 & 7.66 & 10.93 \\
\hline $\mathbf{T}_{7}$ & $\mathrm{~V}_{7}$ & Vikram & 90.00 & 6.85 & 8.63 & 14.06 \\
\hline $\mathbf{T}_{8}$ & $\mathrm{~V}_{8}$ & Swathi & 87.00 & 6.26 & 7.4 & 7.93 \\
\hline \multicolumn{3}{|c|}{ Mean } & 95.12 & 6.53 & 7.52 & 10.41 \\
\hline \multicolumn{3}{|c|}{ F-test } & S & S & $\mathrm{S}$ & S \\
\hline \multicolumn{3}{|c|}{ C.D. at $0.5 \%$} & 0.339 & 0.284 & 0.284 & 0.594 \\
\hline \multicolumn{3}{|c|}{ S.Ed( \pm$)$} & 0.728 & 0.610 & 0.610 & 1.275 \\
\hline
\end{tabular}

Table.4 Performance of coriander varieties based on quality attributes

\begin{tabular}{|c|c|c|c|c|c|}
\hline $\begin{array}{l}\text { Treatment } \\
\text { symbol }\end{array}$ & $\begin{array}{l}\text { Notation } \\
\text { symbol }\end{array}$ & Varieties & T.S.S( ${ }^{\mathbf{0}}$ Brix) & Protein (\%) & $\begin{array}{l}\text { Ascorbic } \\
\text { (mg/100gm) }\end{array}$ \\
\hline $\mathbf{T}_{\mathbf{1}}$ & $\mathrm{V}_{1}$ & WS-201 & 4.71 & 21.28 & 157.58 \\
\hline $\mathbf{T}_{\mathbf{2}}$ & $\mathrm{V}_{2}$ & Suruchi & 5.27 & 25.76 & 151.72 \\
\hline $\mathbf{T}_{\mathbf{3}}$ & $\mathrm{V}_{3}$ & Desi & 6.20 & 27.04 & 208.60 \\
\hline $\mathbf{T}_{\mathbf{4}}$ & $\mathrm{V}_{4}$ & Jyoti & 4.62 & 20.93 & 151.05 \\
\hline $\mathbf{T}_{\mathbf{5}}$ & $\mathrm{V}_{5}$ & Ramses & 5.30 & 21.48 & 197.95 \\
\hline $\mathbf{T}_{\mathbf{6}}$ & $\mathrm{V}_{6}$ & Green Aroma & 5.51 & 20.84 & 190.00 \\
\hline $\mathbf{T}_{\mathbf{7}}$ & $\mathrm{V}_{\mathbf{7}}$ & Vikram & 5.10 & 21.33 & 175.20 \\
\hline $\mathbf{T}_{\mathbf{8}}$ & $\mathrm{V}_{8}$ & Swathi & 5.17 & 23.82 & 175.42 \\
\hline & Mean & & 5.24 & 22.81 & 175.94 \\
\hline & F-test & & $\mathrm{S}$ & $\mathrm{S}$ & $\mathrm{S}$ \\
\hline & C.D. at $\mathbf{0 . 5 \%}$ & & 0.466 & 2.220 & 4.248 \\
\hline & S.Ed( $\mathbf{n}$ & & 0.217 & 1.035 & 1.981 \\
\hline
\end{tabular}

The data revealed that significantly highest leaf yield plot $^{-1}(\mathrm{~kg})$ was recorded in variety Desi $(419.52 \mathrm{~kg})$ than all other variety. This variety was followed by Green Aroma $(417.20 \mathrm{~kg}), \quad$ Suruchi $\quad(369.52 \mathrm{~kg}) \quad$ Swathi
$(355.36 \mathrm{~kg})$ and Jyoti $(348.72 \mathrm{~kg})$ and minimum leaf yield $\operatorname{plot}^{-1}(\mathrm{~kg})$ was obtained in variety V1 WS-201 $(316.72 \mathrm{~kg})$. The greater leaf number on November sown crop might have helped in the production of more 
metabolites and consequent growth accumulation of total solids which ultimately resulted in the production of larger amount of green leaf yield. November month showing the favourable environmental condition to grow the crop in earlier better leaf yield can be obtained Govindaraj et al., (2019). Highest seed yield plot $^{-1}(\mathrm{~kg})$ was observed in Desi $(214.04 \mathrm{~kg})$ and other treatments found next in order in this regard as Suruchi (152.80) Jyoti (182.16), Green Aroma (175.60) and Ramses (151.20). Lowest seed yield plant ${ }^{-1}(\mathrm{~kg})$ was found in variety Vikram (118.88kg).

Data in respect of TSS ( ${ }^{0}$ Brix) as affected by variety are presented in Table 4. It is evident from the data that TSS ( ${ }^{0}$ Brix) was significantly affected by varieties. The highest TSS ( ${ }^{0}$ Brix) was found in treatment Desi (6.20) and other variety found next in order in this regard as Suruchi (5.27), Ramses (5.30), Green Aroma (5.51), Vikram (5.10) and Swathi (5.17). Lowest TSS ( ${ }^{0}$ Brix) was found in treatment WS-201 (4.71). The highest protein (\%) content was found in treatment Desi (27.04) and other variety found next in order in this regard as Suruchi (25.76), Ramses (21.48), Vikram (21.33), Swathi (23.82), WS-201 (21.28), Green Aroma (20.93). The highest Ascorbic acid (mg/ $100 \mathrm{~g}$ ) was found in treatment Desi (208.60 $\mathrm{mg} / 100 \mathrm{~g}$ ) and other variety found next in order in this regard as Ramses (197.95 mg/ 100g), Green Aroma (190.00 mg/ 100g), Vikram (175.20 mg/ 100g) and Swathi (175.42 mg /100g), Jyoti (151.05 mg /100g).

In conclusion among the different varieties of coriander Green Aroma and Desi varieties were found superior in terms of growth and yield and quality attributing traits. Based on the results obtained maximum plant height, number of branches, number of leaves, days to $50 \%$ flowering, number of umbels was found better in the variety Green aroma. Herbage Yield, seed yield, T.S.S $\left({ }^{0}\right.$ Brix $)$, protein and ascorbic acid was found better in the variety Desi. It conclude that desi variety was found better in terms of yield and quality.

\section{References}

Akshata Hongal, Basavaraja N., Shivanand Hongal, Hegde N.K. and Sudheesh Kulkarni (2018). Evaluation of Coriander (Coriandrum sativum L.) Genotypes for Yield and Quality under Hill Zone (Zone-9) of Karnataka, India. Int.J.Curr.Microbiol.App.Sci. $\quad$ 7(5): 2494-2502

Anilkumar GS, Umesha K, Maruthiprasad $B N$, Shivapriya $M$ and Nithin Kumar VC (2018). Varietal response of coriander (Coriandrum sativum L.) for growth, yield and quality attributes. Journal of Pharmacognosy and Phytochemistry; SP3: 35-39.

Bajad G B, Dahale M H and Nandeshwar V N (2017). Performance of Different Coriander Varieties for Seed Yield. $J$ Krishi Vigyan, 5(2): 132-137

Carubba A, Calabrese I, Torre R and Kock O (2002). Cultivation trials of coriander (Coriandrum sativum L.) in a semi-arid Mediterranean environment. Acta Hort 576: 237-242

Govindaraj K, Balakrishnan S, Shoba N and Somasundaram E (2019). Influence of growing environment on growth and yield of fenugreek leaves under shade net and open condition. International Journal of Chemical Studies; 7(3): 2102-2105.

Harshavardhan G, Pavani P, Suryakumari S, Reddy RVSK, Salomi Suneetha DR, Sujatha RV and Giridhar K (2018). Evaluation of coriander germplasm for green leaf purpose and quality parameters in summer under shade net and in rabi under open field conditions. International Journal of Chemical Studies; 6(6): 1706-1710 
Islam Md. Shahanur, Abul Hasnat M Solaiman, S M Anamul Arefin and Rinita Islam (2019). The growth and leaf yield performance of several coriander varieties as influenced by organic nutrient sources during summer. Asian Australas. J. Biosci. Biotechnol. 4 (1), 14-23

Kalidasu G, Sarada C and Reddy T Y (2008). Eficacy of biofertilizers on the performance of rainfed coriander (Coriandrum sativum L.) in vertisols. $J$ Spices and Aromatic Crops 17(2): 98102.
Mohammed Farooq, S. R. Mulla, A. G., Patil, S. J. Imamsaheb and R. V. Hegde (2017). Performance of Coriander Genotypes with Respect to Yield Parameters in North Eastern Transitional Tract (Zone-I) of Karnataka. 6744 Trends in Biosciences 8 (24).

Surya Raj and P. Anitha (2018). Effect of growing conditions on growth and herbage yield of coriander. Journal of Tropical Agriculture 55 (2): 200-204.

\section{How to cite this article:}

Lavanya Gandepalli and Prasad, V. M. 2020. Evaluation of Coriander (Coriandrum sativum L.) Varieties in Prayagraj Agro-climatic Conditions. Int.J.Curr.Microbiol.App.Sci. 9(12): 10861091. doi: https://doi.org/10.20546/ijcmas.2020.912.130 